\title{
Evaluation of Classroom Based on AIDCA Rule in the First-Grade High School Students in Pakdasht County
}

\author{
Hoseinali Taghipoor \\ Associate Professor, Islamic Azad University, Chalos Branch \\ Marzieh Moniri \\ MA in Ecuational Science
}

Doi:10.5901/mjss.2016.v7n4s1p23

\begin{abstract}
Assessment is one of the most important factor in management planning, particularly in educational management. It helps link various organizational factors to management and classroom including curriculum, teaching and learning technology, organization, management, and learners. The main objective of the research is to evaluate classroom management based on AIDCA approach at high schools in Pakdasht County. The research method is a descriptive-survey method. The study population consisted of 307 first-grade high school teachers in Pakdasht County. Relying on census technique, all of them were chosen as sample. Accordingly, a standard questionnaire was developed and necessary data were collected, and questions were addressed. The results suggest that interests, belief, demand, consideration and observance of managerial perspectives remained at a desirable level in classroom on the part of teachers of high schools in Pakdasht County. Further, type of schools, gender, education degree of teachers, age, academic discipline of teachers, their job tenure arranged demographically showed no significant difference across the teachers according to demographic criteria. Application of AIDCA to educational system is helpful in effective learning.
\end{abstract}

Keywords: assessment, classroom, AIDCA rule, Pakdasht County

\section{Introduction}

Assessment is one of the most important management planning, particularly in educational management; if properly performed, it can provide useful information on how to design and implement educational and curriculum programs for teachers, and serve as a good basis for evaluating educational centers' performance. Assessment is an internal part of a design process, which is linked to development in the future due to administrative performance in the past and present. Assessment helps relate various organizational and classroom management factors such as curriculum, teaching and learning technology, organization and management and learners. For this reason, assessment includes two aspects; the one is learners, and the other is school factors. Reinforcement of the two aspects would lead to the full implementation of educational system project and teaching and learning and application of technology in classroom management (Taghipour and Khazaee, 2009).

At the present time, we are facing problems such as lacking incentive, trust, and belief in class and classroom management, and actually one-sidedness of duty at classroom. In order to know to what extent teachers remain loyal to class principles and class management, we decided to study AIDCA rule. In this respect, teachers are required to pay attention to factors such as interest, desire, and trust in action of classroom management, if they would like to manage classroom with AIDCA approach. The factors can be employed evenly when teachers are ready to present it desirably and behave toward learners nicely, knowing how to present contents and build self-confidence in them and gain their trust and know how to organize the, as well as being acquainted with modern technology and having the ability to utilize them, so that they can interest them and obtain excellent results in classroom management (Seif, 2009).

Accordingly, the research aims to determine to what extent teachers use AIDCA approach in classroom (to classroom management), i.e. to what extent AIDCA approach is in agreement with classroom management at high schools in Pakdasht County. 


\section{Research Background and Hypotheses}

Assessment of administrative performance in the development of educational system, particularly classroom management, can invariably account for an array of ambiguities and queries and objections to classroom management. The results of evaluation program studies suggest that directors of classrooms basically find little link between dimensions of evaluation performance and performances useful on the development and influence of class. If an evaluation works, it can cover all faults in the function of school. In choosing dimensions and performances, we need to take precautions, so that we opt for those having influence over learners' learning. Effective teaching sheds light on the main dimensions and performances that are more likely to lead to the development of learners' results; when the fundamental dimensions are chosen, the effectiveness of teaching and clarification of awareness performance are useful for each of the selected dimensions. Although universities have developed quantitatively, it isn't deemed appropriate. Searching for the best methods and approaches following educational activities have been always considered by educational practitioners (Soleimanpour, 2004). In Taghipour (2013), a research on the evaluation of classroom management based on AIDCA approach at Mazandaran universities, it was found that all research questions about the application of AIDCA approach by university professors in Mazandaran Province remained at desirable level; further, research hypotheses developed demographically across university professors showed no significant difference in terms of demographic items. In other words, AIDCA approach in education system and in effective learning was found to be helpful. In Rahimzadeh et al (2008), concerning evaluation of the mental health of parents of children with attentiondeficit/hyperactivity disorder (ADHD) and suggestions for intervention methods, it was found that the level of the mental health of the parents of children with ADHD was significantly lower than that of the parents of normal children $(P<0.001)$. Requirements of preventive program policy-makings were discussed with an aim to promote public health level. In Najafi et al (2009), in regard to the level of the prevalence of attention-deficithyperactivity disorder, conduct disorder, and oppositional defiant disorder (ODD) in primary school students, it was found that the prevalence of behavioral disorders varies according to gender and education of father. The result carries applied implications, as it indicates that primary schools are in need of consultation services and guides in order to prevent and treat behavioral disorders. This can be helpful, if included in educational and health planning, funding and policy making. In Ragheb (2012), regarding the effectiveness of learning strategies for curiosity and interest of mentally retarded pre-primary school students, it was found that mentally retarded pre-primary school in the experimental group where intervention strategies were applied for them outperformed those in the control group; therefore, the implementation of intervention program probably can increase mentally-retarded pre-primary school students' performance with respect to curiosity and interest, and prepare them better to enter primary school and understand educational concepts. In Rezaee et all (2008), regarding a pattern for generating interest and motivation for study and research; investigation of its effectiveness in secondary school students, it was found that the application of the designed pattern in a research-centered context in Experimental Science course could help the students achieve higher personal efficiency in this subject matter, and attach more importance to Experimental Science course and show greater satisfaction with this subject matter, as well as putting more effort into scientific and research activities. Generally speaking, the results of the present research suggest that the proposed pattern assumes a determining role in generating interest and motivation in students for study and research activities. In Fazlollahi-Ghomshi and Malekitavana (2012), regarding relationship between religious growth and mental health of students, it was found that a positive relationship exists between religious growth and mental health of students. Correlation between the rate of religious growth and mental health of female and male students was different; despite the greater value of the mean score of male students' religious growth and the mental health of female students, no significant difference was seen between them. Relationship between religious growth and mental health of male students was positive and significant, but that of female students was positive. Iraji and Ziaee (2008), in a research entitled 'the application of time data for improving sale management, asserted that identifying purchase and sale rules can help business managers optimize sale management by considering time factor, in the sense that they are able to increase their trading system profitability with respect to the importance of the time of particular transactions. Zamanian and Moghadamcharkari (2008), in a research entitled "study of the behavior and classification of customers using data mining at universities, stated that "usage mining" is a subset of web mining focusing on techniques which are able to forecast user' behavior during conversation via web, dealing with duplicate data obtained from interaction with the web. Designing and restructuring of website for effectiveness and greater efficiency, making change in the management of website, and eventually improving the management of respective organization using the processing of data obtained from users are seen as the results of the field of web mining. Safaee et al (2009), in their article, proposed a new method called historical simulation in order to calculate risk value using the previous scenarios of a retailer in day market. The method taps into old data as guideline for what will happen in the future. The results indicated that the significance level of the techniques 
is $99 \%$. Teresy (2012), in his research, contends that you may have the best abilities and competencies, and the best work experience among your colleagues, but you cannot be promoted when you are not superior in the eyes of people, so you will not experience a rise in your salary, you better let people see you, be seen in associations and conferences, make yourself available for taking on tasks and different positions, let yourself be recognized as a decent, capable, and perfectionist person. If you have a right point of view, you need to make sure that people have a right attitude toward you, and you will get the success you are looking for. Teresy (2010), in another research entitled "stop giving false excuses", argues that you can always give a variety of excuses for not reaching your goals, life is difficult for everyone, but successful people achieve their goals in spite of all obstacles, and do everything right in its time; they are not slaves of instant gratification, and think of long-term satisfaction, they set goals, try hard and focus all their effort on work at hand, they repeat good habits long enough to make them become part of their secondary nature, the task requires high personal discipline.

Given the main objective of the research, determining the level of teachers' attention, belief, desire and action in classroom management in the first-grade high school classes in Pakdasht County, the research question is here raised as follows;

To what extent do teachers pay attention to, and have interest and belief in and desire and act for classroom management?

\section{Research Methodology}

\subsection{Research method}

Given the fact that research method is selected based on type and nature of research subject, the method of the present research is descriptive and evaluative according to type and nature of the subject.

\subsection{Population and study sample}

The study sample consisted of all high school teachers in Pakdasht County (both public and non-profit high schools), the number of which stood at 307 teachers. In order to choose sample, we used census method and the questionnaire was distributed among 307 individuals, among which $57 \%$ was male and $43 \%$ female with respect to sex, $20 \%$ younger than 25 years old, $45 \%$ between $26-35$ years of age, $21 \%$ between $36-45$ years of age, $12 \%$ between 46 and 55 years of age, and $2 \%$ older than 55 years of age in terms of age variable, and $92 \%$ with bachelor degree, and $8 \%$ with higher degrees in terms of education level, and $21 \%$ with less than 5 -year job tenure, $28 \%$ between 5 and 10 years of job tenure, $37 \%$ between 11 and 15 years of job tenure, 10\% between 16 and 20 years, 4\% between 21 and 25 years, and $87 \%$ of schools were public and 135 of them were private, in terms of school type.

\subsection{Method of information collection}

The method of data collection in this research was library and field study. In other words, the definitions and features of the research variables were obtained from library studies, visiting libraries, articles, and necessary statistical information was obtained from distribution of questionnaire among statistical sample.

\subsection{Research validity and reliability}

In this research, in order to develop questionnaire, a standard questionnaire was used, which needed confirmation of validity and reliability. For ensuring the reliability and validity of the measuring tool, there are a number of different methods. In the present research, Cronbach's alpha test was used for examining reliability. Since the obtained value (0.952) is greater than 0.70 , it suggests the good reliability of the test.

\subsection{Data analysis}

Having collected necessary data and information by questionnaire, all of them were coded, and then were fed into Excel software. For analysis of general and demographic data, items (age, sex, education, etc.,) and mostly descriptive statistic by means of Excel were used. Moreover, kruskal-Wallis test and binomial test were used to analyze data. 


\section{Research Findings}

The results of kruskal-Wallis test and binomial test are as follows;

Table 1. Kruskal-Wallis test

\begin{tabular}{|l|l|c|c|c|}
\hline Main factor & Variables & Chi-Square & Degree of freedom & Significance level \\
\hline AIDCA approach & Sex & 0.011 & 1 & 0.916 \\
\hline AIDCA approach & Type of school & 0.062 & 1 & 0.804 \\
\hline AIDCA approach & Education degree & 0.868 & 1 & 0.352 \\
\hline AIDCA approach & Age & 1.811 & 4 & 0.770 \\
\hline AIDCA approach & Job tenure & 0.511 & 4 & 0.972 \\
\hline AIDCA approach & Education discipline & 6.450 & 9 & 0.694 \\
\hline
\end{tabular}

Given that the significance levels of the variables are greater than 0.05 , it can be concluded that there is no difference between the components of AIDCA in terms of sex, type of school, education degree, age, job tenure, and education discipline.

Table 2. Binomial test (success test)

\begin{tabular}{|c|c|c|c|c|c|c|}
\hline Significance level & Ratio of test & Ratio of observations & number & range & \multicolumn{2}{|c|}{ Research factor } \\
\hline 0.000 & 0.6 & $\begin{array}{l}0.0 \\
1.0 \\
1.0\end{array}$ & $\begin{array}{c}0 \\
307 \\
307\end{array}$ & $\begin{array}{l}\geq 3 \\
<3\end{array}$ & $\begin{array}{l}\text { Group } 1 \\
\text { Group } 2 \\
\text { total }\end{array}$ & Attention \\
\hline 0.000 & 0.6 & $\begin{array}{l}0.0 \\
1.0 \\
1.0\end{array}$ & $\begin{array}{c}14 \\
293 \\
307\end{array}$ & $\begin{array}{l}\geq 3 \\
<3\end{array}$ & $\begin{array}{l}\text { Group } 1 \\
\text { Group } 2 \\
\text { total }\end{array}$ & Belief \\
\hline 0.000 & 0.6 & $\begin{array}{l}0.1 \\
0.9 \\
1.0\end{array}$ & $\begin{array}{c}28 \\
279 \\
307\end{array}$ & $\begin{array}{l}\geq 3 \\
<3\end{array}$ & $\begin{array}{l}\text { Group } 1 \\
\text { Group } 2 \\
\text { total }\end{array}$ & Demand \\
\hline 0.000 & 0.6 & $\begin{array}{l}0.0 \\
1.0 \\
1.0\end{array}$ & $\begin{array}{c}14 \\
293 \\
307\end{array}$ & $\begin{array}{l}\geq 3 \\
<3\end{array}$ & $\begin{array}{l}\text { Group } 1 \\
\text { Group } 2 \\
\text { total }\end{array}$ & Interest \\
\hline 0.000 & 0.6 & $\begin{array}{l}1.0 \\
0.9 \\
1.0\end{array}$ & $\begin{array}{c}42 \\
265 \\
307\end{array}$ & $\begin{array}{l}\geq 3 \\
<3\end{array}$ & $\begin{array}{l}\text { Group } 1 \\
\text { Group } 2 \\
\text { total }\end{array}$ & Action \\
\hline
\end{tabular}

The above table is the results of binomial test. Given the fact that the significance level is less than 0.05 , it suggests that Pakdasht teachers' attention, demand, interest, and action remain at a desirable level.

\section{Discussion, Conclusion and Helpful Suggestions}

Given the great importance of evaluation, evidence shows that this sensitive task is not pursued in most educational institutions, particularly in a modern and integrated fashion, as they treat it with compromise. The reason for this may be because of lack of enough time allocated for this, lack of evaluation tools and methods, lack of experts with educational skills, or the complexities of evaluation per se, which leads to such compromise. In the present research, we determined the level of teachers' attention, interest, belief, and action for classroom management in first-grade high school at Pakdasht County. Given the results of the present research and research mentioned earlier, we can perform some comparisons in this regard as follows;

Results of binomial test suggest that Pakdasht teachers' belief remain at a desirable level.

The finding is in line with that of Teresy (2012), thus it seems that one of the ways of promoting scientific level and directing students' education toward their lessons, discussions and educational progress is to raise teachers' quality of self-understanding knowledge, so that it can be passed on to students and institutionalize educational and scientific development, and effort in them.

$>$ Results of binomial test suggest that Pakdasht teachers' demands remain at a desirable level. 
The finding of the research is in line with that of Safaee et al (2004). By considering teachers' demands, particularly scientific and educational in different fields, the foundations for work based on their sense of responsibility are provided; this can favorably influence the process of education in schools, particularly at classroom.

$>$ Results of binomial test suggest that Pakdasht teachers' attention remain at a desirable level.

We can find this finding to be in line with that of Teresy (2010). We need to bear in mind that teachers' attention, and taking account of circumstances in which they can focus on concepts and principles of teaching at classroom, the foundations for reflection and perfection in the process of education are provided.

$>$ Results of binomial test suggest that Pakdasht teachers' action based on managerial viewpoint remain at a desirable level.

The finding is in line with that of Taghipour (2001). We can argue that the presence of teachers who are bound by managerial viewpoints at classroom can provide a safe space along with peace for learners, as well as applying managerial principles in classroom, so learning may appeal to them and be effective.

Regarding the research findings, some suggestions are provided as follows;

Use of the information of expert and experienced and veteran individuals with respect to AIDCA approach.

Documentation of failed classroom management processes, and trial and error methods used in the past.

Identification of the link between classroom management and benefits of business rules and its application in education system.

Use of intuition and insight in a framework that directs management of education system into programs based on business rules and educational programs.

Building up the culture of application of AIDCA approach, which is insisted and supported.

Building technical and tactical infrastructures in education system based on AIDCA approach

Taking account of learners as client and respecting their preferences and demands and desires and interests.

Teachers are required to know that education organization like other organizations abide by managerial principles, so the application of useful rules of other systems in education system, e.g. AIDCA approach, can be effective in learning.

Application of AIDCA approach can empower learners in learning tasks, as well as empowering teachers in getting data and concepts across.

\section{For Future Research}

In addition to questions that it answers, every research lays the foundations for raising new questions. At this point, we refer to items that can serve as the basis of other research:

* It is recommended that AIDCA approach be implemented in education system at various levels.

* It is recommended that some research be conducted on AIDCA approach in various academic disciplines separately.

* It is recommended that business rules which are customer-based be embedded in education planning program.

* It is recommended that acquaintance with AIDCA approach and how to apply it in education and workshop system and programs, as well as designing it, be pursued.

* Investigate the weaknesses and strengths and opportunities and threats of applying AIDCA approach in classroom management.

* For obtaining results, it is recommended that other results such as structured interviews be used, as well as the results of the report itself.

\section{References}

Fazlollahigholshi, S. Malekitavana, M. (2012). Relationship between religious growth and metal health of students. Islamic sand Psychology studies, volume 6, issue 10, pp. 105-118

Iraji, A. Minaee, B. (2008). Application of time data for improving sale management. $2^{\text {nd }}$ Conference on Iranian Database, Tehran

Najafi, M. Foladchang, M. Alizadeh, H. Mohammadifar, m. (2009). Level of the prevalence of attention-deficithyperactivity disorder, conduct disorder, and oppositional defiant disorder (ODD) in primary school students, research on exceptional children, issue 33, pp. 239-254

Ragheb, H. (2012). Effectiveness of learning strategies in mentally retarded pre-preliminary school students' curiosity and interest; a study on exceptional children. Issue 44, pp. 55-68

Rahimzadeh, S. Pouretemad, H.M, Samikarani, S. Mohammadi, A. (2008). Evaluation of the mental health of parents of children with 
attention-deficit/hyperactivity and suggestion for intervention methods. Evolutional psychology Journal Iranian Psychology, issue 16, pp. 355-366

Rezaee, A. Ghadampour, Pashasharifi, H. (2008). A pattern for generating interest and motivation for study and research: study of its effectiveness in secondary school students, Journal of Educational Innovations, issue 25, pp. 151-186

Seif, A. (2009). Education measurement and evaluation. Tehran: Doran Publication

Soleimanpour, J. (2004). New teaching methods, Tehran: Ahsan Publication

Taghipour and Khazaee, H. (2009). Management of education-centered school. Islamic Azad University, Chalos Branch

Taghipour, Hoseinali, 2014, Evaluation of class management based on AIDCA Approach at the Universities of Mazandaran Province, Journal of Applied Environmental and Biological Sciences

Teresy, B. (2010). Stop giving excuse. Translated by Beqomian, Zh. 2013. Tehran: Sepid Publication

Teresy, B. (2012). Management and marketing and improvement. Translated by Beqomian Zh, 2013, Tehran: Sepid Publication

Zamanian, M. Moghadamcharkari, N (2008). Study of behavior and classification of customers using data mining at universities, $2^{\text {nd }}$ Conference on Iran Database, Tehran. 